\title{
Evaluation of the Physicochemical, Spectral, Thermal and Behavioral Properties of Sodium Selenate After the Energy of Consciousness Healing Treatment
}

\author{
Mahendra Kumar Trivedi ${ }^{1}$, Alice Branton ${ }^{1}$, Dahryn Trivedi ${ }^{1}$, Gopal Nayak ${ }^{1}$, \\ Ariadne Esmene Afaganis ${ }^{1}$, Barbara Marie Bader ${ }^{1}$, Brian A. Weekes ${ }^{1}$, Daphne Luisa Dumas ${ }^{1}$, \\ Denise Marie Fiedler ${ }^{1}$, Dennille Mellesia Smith ${ }^{1}$, Desi Pano ${ }^{1}$, Donna Felice Galla ${ }^{1}$, \\ Donna Maria Alija ${ }^{1}$, Elaine Barbara Mullins' ${ }^{1}$, Elaine M. Scorza', Ellia O'Donnell, \\ Fabio Massimo Paciucci ${ }^{1}$, Frances Goodman Warlick ${ }^{1}$, Haddon Norman Salt ${ }^{1}$, Inthirani Arul ${ }^{1}$, \\ Jacqueline Y. Andrews ${ }^{1}$, James Jay McLeran ${ }^{1}$, James Stephen Burnett ${ }^{1}$, Jean Caroline White ${ }^{1}$, \\ Parthasarathi Panda ${ }^{2}$, Kalyan Kumar Sethi ${ }^{2}$, Snehasis Jana ${ }^{2, *}$ \\ ${ }^{1}$ Trivedi Global, Inc., Henderson, Nevada, USA \\ ${ }^{2}$ Trivedi Science Research Laboratory Pvt. Ltd., Bhopal, India
}

Email address:

publication@trivedieffect.com (S. Jana)

${ }^{*}$ Corresponding author

To cite this article:

Mahendra Kumar Trivedi, Alice Branton, Dahryn Trivedi, Gopal Nayak, Ariadne Esmene Afaganis, Barbara Marie Bader, Brian A. Weekes, Daphne Luisa Dumas, Denise Marie Fiedler, Dennille Mellesia Smith, Desi Pano, Donna Felice Galla, Donna Maria Alija, Elaine Barbara Mullins, Elaine M. Scorza, Ellia O'Donnell, Fabio Massimo Paciucci, Frances Goodman Warlick, Haddon Norman Salt, Inthirani Arul, Jacqueline Y. Andrews, James Jay McLeran, James Stephen Burnett, Jean Caroline White, Parthasarathi Panda, Kalyan Kumar Sethi, Snehasis Jana. Evaluation of the Physicochemical, Spectral, Thermal and Behavioral Properties of Sodium Selenate After the Energy of Consciousness Healing Treatment. Science Journal of Analytical Chemistry. Vol. 5, No. 2, 2017, pp. 28-37. doi: 10.11648/j.sjac.20170502.12

Received: February 27, 2017; Accepted: April 10,2017; Published: May 8, 2017

\begin{abstract}
Sodium selenate was considered for the current study, which is an important nutrient used for the prevention and treatment of cancer, inflammatory diseases, diabetes, etc. The objective of the current study was to examine the impact of The Trivedi Effect ${ }^{\circledR}$ - Consciousness Energy Healing Treatment (Biofield Energy Healing treatment) on the physico-chemical, thermal, and behavioral properties of sodium selenate using PXRD, PSD, FT-IR, UV-vis, TGA, and DSC analysis. Sodium selenate sample was divided into two parts - one part was control, while another part was treated with the Biofield Energy remotely by twenty renowned Biofield Energy Healers and termed as the treated sample. The PXRD analysis showed that the crystallite size of the treated sample significantly altered in the range of $-50.01 \%$ to $59.97 \%$ compared to the control sample. The average crystallite size of the treated sample was significantly increased by $7.32 \%$ compared with the control sample. The PSD analysis indicated that the particle size of the treated sample at $\mathrm{d}_{10}, \mathrm{~d}_{50}$, and $\mathrm{d}_{90}$ values were increased by $6.84 \%, 8.04 \%$, and $3.04 \%$, respectively compared with the control sample. Thus, the surface area of the Biofield Energy Treated sample was significantly decreased by $7.41 \%$ compared with the control sample. The FT-IR spectra indicated the presence of sharp and strong absorption bands at 887 and $888 \mathrm{~cm}^{-1}$ due to the $\mathrm{Se}=\mathrm{O}$ stretching in the control and treated sample, respectively. The wavelength of maximum absorbance from the UV-vis spectroscopic analysis of the Biofield Energy Treated sample (205.2 nm) was increased by $0.39 \%$ compared to the control sample $(204.4 \mathrm{~nm})$. The TGA analysis revealed the total weight loss of the Biofield Energy Treated sample was significantly reduced by $12.63 \%$ compared with the control sample. The DSC analysis showed that the vaporization temperature of the Biofield Energy Treated sample $\left(95.14^{\circ} \mathrm{C}\right)$ was increased compared to the control sample $\left(94.28^{\circ} \mathrm{C}\right)$. But, the latent heat of vaporization was decreased significantly in the treated sample by $43.67 \%$ compared to the control sample. Thus, The Trivedi Effect ${ }^{\circledR}$ - Consciousness Energy Healing Treatment might lead to generate a new polymorphic form of sodium selenate, which would have better powder flowability and long-term storage stability compared with the control sample. The Biofield Energy Treated sodium selenate would be helpful for designing better nutraceutical/pharmaceutical formulations against immunological disorders, inflammatory diseases, aging, stress, infectious
\end{abstract}


diseases, Alzheimer's disease, cancer, diabetes, heart diseases, etc.

Keywords: Sodium Selenate, The Trivedi Effect ${ }^{\circledR}$, Consciousness Energy Healing Treatment, Biofield Energy Healers, PXRD, Particle Size, TGA, DSC

\section{Introduction}

Sodium selenate $\left(\mathrm{Na}_{2} \mathrm{SeO}_{4}\right)$ is an important common ingredient in the multivitamins and livestock feed as a source of selenium [1]. Selenium is an essential trace element, which has been reported to postpone the Alzheimer's symptoms in the elderly people and delay the initiation signs of skin aging [2,3]. Recent studies have shown that this compound protects various enzymes against the toxicity caused by heavy metals i.e. $\mathrm{Pb}, \mathrm{Al}, \mathrm{Cu}, \mathrm{Cd}$, etc. [4]. The role of selenium in biological systems have been investigated over the years to demonstrate the effects of selenium, for example, it helps to promote a healthy liver, acts as an antioxidant [5], prevent cancers [6], normal metabolic reactions [7] and heart disease [2]. It was also known to provide protection from reactive oxygen species-induced cell damages [2, 3]. Sodium selenate has various other applications in the glass industry [8], an ingredient in some insecticides (against mites, aphids, and mealybugs) and fungicides $[9,10]$. Excessive selenium in the diet may lead to a condition like selenosis with the symptoms of gastrointestinal upsets, white blotchy nails, hair loss, garlic breath odour, irritability, fatigue, and mild nerve damage [11]. Chronic exposure to sodium selenate may cause severe lung, kidney, and liver damage [12, 13]. Selenium (Se) bioavailability and toxicity, depend on their chemical form or speciation. Sodium selenate can exist in the +6 oxidation state. Sodium selenate is the most mobile forms of selenium because of its high solubility, stable under alkaline and oxidizing conditions and less toxic [14]. It is evident that many people do not consume enough Se to support the maximum expression of selenoenzymes [15]. It has been found that selenium concentration is too low in food produced in most of the country and estimated that Sedeficient people in the world to be in the range of 500-1000 million $[16,17]$.

It is very important to focus on some of the ways to increase selenium concentration in diets with the help of nutraceutical in order to improve the planet's scarce Se resources for human health and well-being. There is an enormous nutraceuticals demand in the form of the herbomineral formulations for maintaining overall good health [18]. Therefore, sodium selenate was used in a newly designed formulation along with zinc chloride, magnesium gluconate, and Withania somnifera root extract. This herbomineral formulation can be used for the prevention and treatment of various human disorders and better quality of life.

Electromagnetic waves can be discharged by the human body in the form of bio-photons that surrounds the body, which is generated from the continuous movement of the electrically charged particles, i.e. ions, cells, etc. inside the body, collectively called Biofield Energy. Biofield Energy can be harnessed from the environment or the "universal energy field" and can be transmitted into any living or nonliving object(s) by the Biofield Energy Healing Practitioners. The process of receiving the Biofield Energy and respond into a useful way by the object is called as Biofield Energy Healing [19-21]. The National Center of Complementary and Integrative Health (NCCIH) has recognized and accepted Biofield based Energy Therapies (Biofield Energy Healing) as a Complementary and Alternative Medicine (CAM) health care approach in addition to other therapies, medicines and practices such as yoga, meditation, natural products, deep breathing, Qi Gong, Tai Chi, chiropractic/osteopathic manipulation, massage, special diets, Ayurvedic medicine, homeopathy, acupressure, acupuncture, hypnotherapy, Reiki, healing touch, movement therapy, pilates, mindfulness, traditional Chinese herbs and medicines, essential oils, naturopathy, aromatherapy, applied prayer, etc. (very common in all religions, like Hinduism, Christianity, Buddhism, Judaism, etc.) [22]. Biofield Energy Healing (also known as The Trivedi Effect ${ }^{\circledR}$ ) has the astonishing capability for alteration of the characteristic properties of the several non-living materials and living organisms. The impact of The Trivedi Effect ${ }^{\circledR}$ scientifically studied and has been proven in various fields including materials science [23-25], organic compounds [26-28], nutraceuticals $[29,30]$, pharmaceuticals $[31,32]$, microbiology [33-35], agricultural [36, 37], biotechnology [38-40], genetics [41, 42].

It has been found that the bioavailability of inorganic selenium is lower than the organic forms of selenium i.e. selenium methionine [16]. The physicochemical properties like crystalline structure, crystallite size, particle size, surface area, etc. of a drug play an important role in stability, solubility, and bioavailability [43]. The crystalline nature, particle size, surface area, chemical and thermal behavior of an atom/ion might be altered due to the Biofield Energy Healing Treatment (The Trivedi Effect ${ }^{\mathbb{R}}$ ) through the possible mediation of neutrinos [44]. Hence, the current study was designed to evaluate the impact of The Trivedi Effect ${ }^{\circledR}$ Consciousness Energy Healing Treatment on the physicochemical, thermal, and behavioral properties of sodium selenate using various analytical techniques include powder $\mathrm{X}$-ray diffraction (PXRD), particle size distribution analysis (PSD), Fourier transform infrared (FT-IR) spectrometry, ultraviolet-visible (UV-vis) spectroscopy, thermogravimetric analysis (TGA), and differential scanning calorimetry (DSC) analysis. 


\section{Materials and Methods}

\subsection{Chemicals and Reagents}

Sodium selenate was procured from Alfa Aesar, USA. All other chemicals used in the experiment were of analytical grade available in India.

\subsection{Energy of Consciousness Healing Treatment Strategies}

Sodium selenate was one of the components of the new proprietary test formulation, and it was used per se as the test compound for the present study. The test compound was divided into two parts, one part of the compound did not receive any Biofield Energy Treatment called as untreated or control sample. The second part of the test compound was treated with the Consciousness Energy Healing Treatment (The Trivedi Effect ${ }^{\circledR}$ ) by a group of twenty renowned Biofield Energy Healers remotely and was denoted as Biofield Energy Treated sample. Eighteen Biofield Energy Healers were remotely located in the U.S.A. and two of which were remotely located in Canada, while the test compound was located in the research laboratory of GVK Biosciences Pvt. Ltd., Hyderabad, India. This Biofield Energy Treatment was provided for 5 minutes through Healer's Unique Energy Transmission process remotely to the test compound under the laboratory conditions. None of the Biofield Energy Healers in this study visited the laboratory in person, nor had any contact with the compounds. Similarly, the control compound was subjected to "sham" healers for 5 minutes, under the same laboratory conditions. The sham healer did not have any knowledge about The Trivedi Effect ${ }^{\circledR}$ - Consciousness Energy Healing Treatment. After that, the treated and untreated samples were kept in similar sealed conditions and characterized using PXRD, PSD, FT-IR, UV-visible spectroscopy, TGA, and DSC analysis.

\subsection{Characterization}

\subsubsection{Powder X-Ray Diffraction (PXRD) Analysis}

The XRD analysis was accomplished on PANalytical X'Pert Pro powder X-ray diffractometer system. The XRD conditions and the sample preparation was followed as per the recent literature $[45,46]$. The crystallite size $(G)$ was calculated from the Scherrer equation $[47,48]$. The crystallite size $(\mathrm{G})$ was calculated by using the following equation (1):

$$
\mathrm{G}=\mathrm{k} \lambda /(\mathrm{b} \operatorname{Cos} \theta)
$$

Where, $\mathrm{k}$ is the equipment constant $(0.5), \lambda$ is the $\mathrm{X}$-ray wavelength $(0.154 \mathrm{~nm})$; $\mathrm{b}$ in radians is the full-width at half of the peaks and $\theta$ the corresponding Bragg angle.

Percent change in crystallite size $(G)$ was calculated using following equation (2):

$\%$ change in crystallite size $=\frac{\left[\mathrm{G}_{\text {Treated }}-\mathrm{G}_{\text {Control }}\right]}{\mathrm{G}_{\text {Control }}} \times 100$

Where, $G_{\text {Control }}$ and $G_{\text {Treated }}$ are the crystallite size of the control and Biofield Energy Treated samples, respectively.

\subsubsection{Particle Size Distribution (PSD) Analysis}

The average particle size and particle size distribution were analyzed using Malvern Mastersizer 2000, UK with a detection range between $0.01 \mu \mathrm{m}$ to $3000 \mu \mathrm{m}$. The PSD conditions and the sample preparation was followed as per the recent literature $[45,46]$.

The percent change in particle size (d) for at below $10 \%$ level $\left(\mathrm{d}_{10}\right), 50 \%$ level $\left(\mathrm{d}_{50}\right)$, and $90 \%$ level $\left(\mathrm{d}_{90}\right)$ was calculated using following equation (3):

$$
\% \text { change in particle size }=\frac{\left[\mathrm{d}_{\text {Treated }}-\mathrm{d}_{\text {Control }}\right]}{\mathrm{d}_{\text {Control }}} \times 100
$$

Where, $\mathrm{d}_{\text {Control }}$ and $\mathrm{d}_{\text {Treated }}$ are the particle size $(\mu \mathrm{m})$ for at below $10 \%$ level $\left(\mathrm{d}_{10}\right), 50 \%$ level $\left(\mathrm{d}_{50}\right)$, and $90 \%$ level $\left(\mathrm{d}_{90}\right)$ of the control and Biofield Energy Treated samples, respectively.

Percent change in surface area $(\mathrm{S})$ was calculated using following equation (4):

$$
\% \text { change in surface area }=\frac{\left[\mathrm{S}_{\text {Treated }}-\mathrm{S}_{\text {Control }}\right]}{\mathrm{S}_{\text {Control }}} \times 100
$$

Where, $\mathrm{S}_{\text {Control }}$ and $\mathrm{S}_{\text {Treated }}$ are the surface area of the control and Biofield Energy Treated samples, respectively.

\subsubsection{Fourier Transform Infrared (FT-IR) Spectroscopy}

FT-IR spectroscopy of sodium selenate was performed on Spectrum two (Perkin Elmer, USA) Fourier transform infrared spectrometer using pressed $\mathrm{KBr}$ disk technique [45, 46].

\subsubsection{Ultraviolet-Visible Spectroscopy (UV-Vis) Analysis}

The UV-Vis spectral analysis was carried out using Shimadzu UV-2450 with UV Probe, Japan. The absorbance spectra and wavelength of maximum absorbance $\left(\lambda_{\max }\right)$ were recorded $[45,46]$.

\subsubsection{Thermal Gravimetric Analysis (TGA)}

TGA analysis was performed using instrument TGA Q50 (TA Instruments, USA) taking $\sim 10$ gm of samples and the remaining TGA conditions were followed as per the recent literature $[45,46]$. The $\%$ change in weight loss (W) was calculated using following equation (5):

$$
\% \text { change in weight loss }=\frac{\left[\mathrm{w}_{\text {Treated }}-\mathrm{W}_{\text {Control }}\right]}{\mathrm{w}_{\text {Control }}} \times 100
$$

Where, $\mathrm{W}_{\text {Control }}$ and $\mathrm{W}_{\text {Treated }}$ are the weight loss of the control and Biofield Energy Treated samples, respectively.

\subsubsection{Differential Scanning Calorimetry (DSC)}

The analysis was performed using the DSC Q20 (TA Instruments, USA) using $\sim 2.5 \mathrm{mg}$ of samples. The remaining DSC conditions were followed as per the recent literature $[45,46]$. The $\%$ change in melting point $(\mathrm{T})$ was calculated using following equation (6):

$\%$ change in melting point $=\frac{\left[\mathrm{T}_{\text {Treated }}-\mathrm{T}_{\text {Control }}\right]}{\mathrm{T}_{\text {Control }}} \times 100$

Where, $\mathrm{T}_{\text {Control }}$ and $\mathrm{T}_{\text {Treated }}$ are the melting point of the 
control and treated samples, respectively.

Percent change in the latent heat of fusion $(\Delta \mathrm{H})$ was

calculated using following equation (7):

$$
\% \text { change in latent heat of fusion }=\frac{\left[\Delta \mathrm{H}_{\text {Treated }}-\Delta \mathrm{H}_{\text {Control }}\right]}{\Delta \mathrm{H}_{\text {Control }}} \times 100
$$

Where, $\Delta \mathrm{H}_{\text {Control }}$ and $\Delta \mathrm{H}_{\text {Treated }}$ are the latent heat of fusion of the control and treated samples, respectively.

\section{Results and Discussion}

\subsection{Powder X-Ray Diffraction (PXRD) Analysis}

The PXRD diffractograms of the control and Biofield Energy Treated sodium selenate showed very sharp and intense peaks (Figure 1) indicating that both these samples were crystalline in nature. The PXRD diffractograms showed the notable changes of the crystallite size of the treated sodium selenate compared with the control sample. From Table 1 (entry 1), the most intense peaks for the control and treated samples were found at $2 \theta$ equal to $18.4^{\circ}$. The crystallite size of the Biofield Energy Treated sodium selenate at $2 \theta$ equal to nearly $27.3^{\circ}, 31.0^{\circ}, 34.3^{\circ}, 37.2,45.1^{\circ}$, $47.4^{\circ}, 48.8^{\circ}, 57.2^{\circ}$, and $60.2^{\circ}$ (Table 1 , entry $3,5,7-9,11,12$, 14 , and 15) was significantly increased from $12.55 \%$ to $59.97 \%$ compared with the control sample. Consequently, at position $2 \theta$ equal to nearly $22.5^{\circ}, 52.9^{\circ}$, and $70.2^{\circ}$ (Table 1 , entry 2,13, and 16), the crystallite size values of the Biofield Energy Treated samples were markedly decreased from $12.49 \%$ to $50.01 \%$ in comparison to the control sample. But, the crystallite size of the control and Biofield Energy Treated sodium selenate at $2 \theta$ equal to nearly $18.4^{\circ}, 28.4^{\circ}, 32.6^{\circ}$, and $45.9^{\circ}$ (Table 1 , entry 1,4 , and 10 ) were the same value. Overall, the average crystallite size of the Biofield Energy Treated sodium selenate was significantly decreased by $7.32 \%$ compared with the control sample.
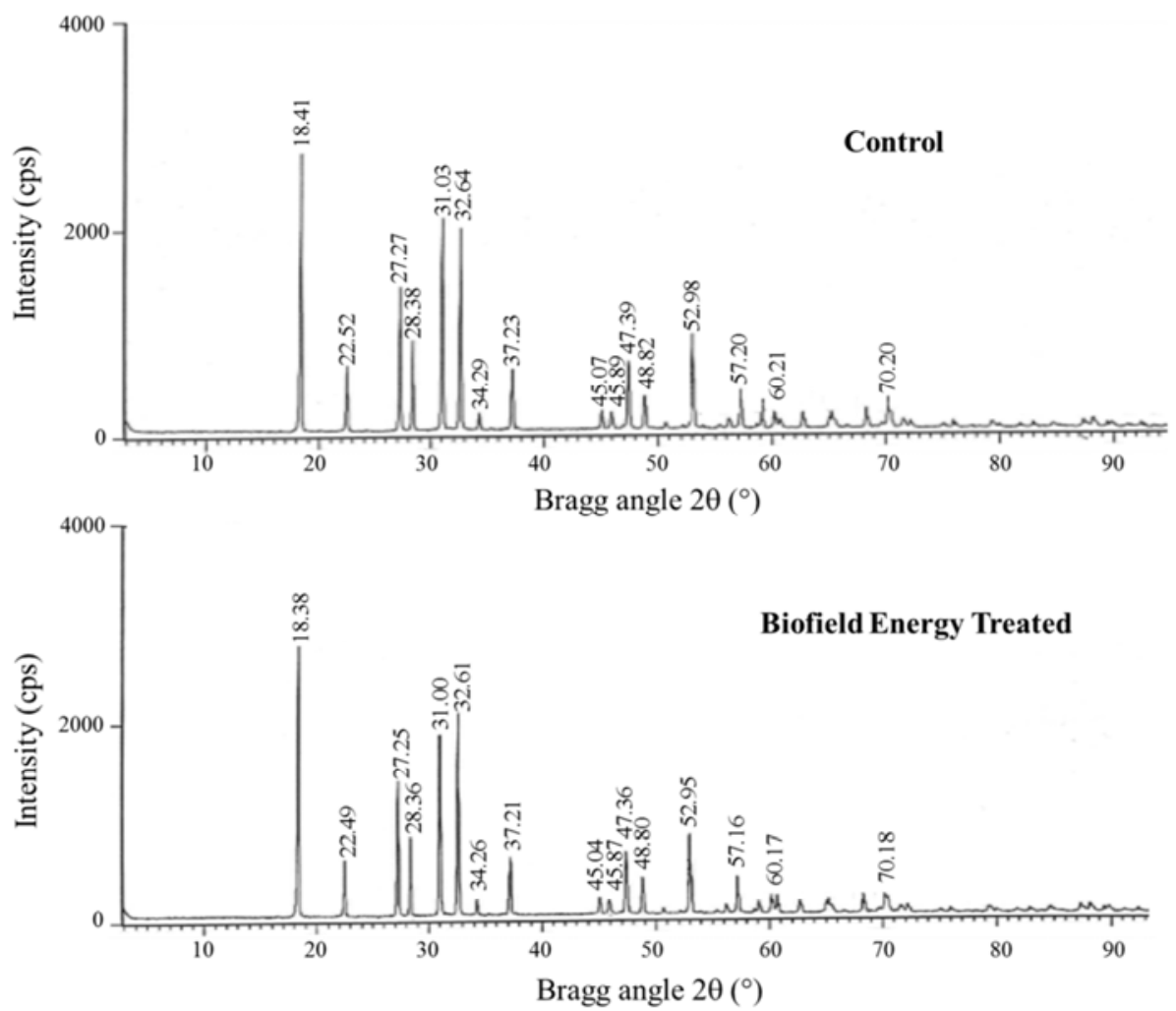

Figure 1. PXRD diffractograms of the control and Biofield Energy Treated sodium selenate.

Table 1. PXRD data for the control and Biofield Energy Treated sodium selenate.

\begin{tabular}{|c|c|c|c|c|c|c|c|c|c|}
\hline \multirow{2}{*}{$\begin{array}{l}\text { Entry } \\
\text { No. }\end{array}$} & \multicolumn{2}{|c|}{ Bragg angle $\left({ }^{\circ} 2 \theta\right)$} & \multicolumn{2}{|c|}{ Relative Intensity (\%) } & \multicolumn{2}{|c|}{ FWHM $\left({ }^{\circ} 2 \theta\right)$} & \multicolumn{3}{|c|}{ Crystallite size ( $\mathrm{G}, \mathrm{nm})$} \\
\hline & Control & Treated & Control & Treated & Control & Treated & Control & Treated & $\%$ change \\
\hline 1 & 18.41 & 18.38 & 100.00 & 100.00 & 0.1004 & 0.1004 & 44.41 & 44.41 & 0.00 \\
\hline 2 & 22.52 & 22.49 & 23.50 & 21.18 & 0.1171 & 0.1338 & 38.33 & 33.54 & -12.49 \\
\hline 3 & 27.27 & 27.25 & 49.53 & 49.11 & 0.1338 & 0.1004 & 33.85 & 45.11 & 33.26 \\
\hline 4 & 28.38 & 28.36 & 32.05 & 29.00 & 0.1004 & 0.1004 & 45.23 & 45.22 & 0.00 \\
\hline 5 & 31.03 & 31.00 & 75.08 & 67.13 & 0.1171 & 0.1004 & 39.02 & 45.50 & 16.62 \\
\hline
\end{tabular}




\begin{tabular}{llllllllll}
\hline \multirow{2}{*}{$\begin{array}{l}\text { Entry } \\
\text { No. }\end{array}$} & \multicolumn{2}{l}{ Bragg angle $\left({ }^{\circ} \mathbf{2} \boldsymbol{\theta}\right)$} & \multicolumn{2}{l}{ Relative Intensity $(\mathbf{\%})$} & \multicolumn{2}{l}{ FWHM $\left({ }^{\circ} \mathbf{2 \theta}\right)$} & \multicolumn{3}{l}{ Crystallite size $(\mathbf{G}, \mathbf{n m})$} \\
\hline & Control & Treated & Control & Treated & Control & Treated & Control & Treated & \% change \\
\hline 7 & 34.29 & 34.26 & 6.00 & 6.01 & 0.1004 & 0.0836 & 45.89 & 55.10 & 20.09 \\
8 & 37.23 & 37.21 & 22.04 & 21.52 & 0.1506 & 0.1338 & 30.85 & 34.72 & 12.55 \\
9 & 45.07 & 45.04 & 6.54 & 6.20 & 0.1004 & 0.0669 & 47.48 & 71.25 & 50.06 \\
10 & 45.89 & 45.87 & 6.08 & 5.31 & 0.1171 & 0.1171 & 40.83 & 40.83 & -0.01 \\
11 & 47.39 & 47.36 & 24.10 & 22.75 & 0.1224 & 0.1020 & 39.29 & 47.14 & 19.99 \\
12 & 48.82 & 48.80 & 11.60 & 13.48 & 0.1224 & 0.1004 & 39.51 & 48.16 & 21.90 \\
13 & 52.98 & 52.95 & 33.44 & 27.76 & 0.1020 & 0.1224 & 48.24 & 40.20 & -16.68 \\
14 & 57.20 & 57.16 & 13.71 & 13.58 & 0.1428 & 0.1224 & 35.13 & 40.98 & 16.64 \\
15 & 60.21 & 60.17 & 5.87 & 6.93 & 0.1632 & 0.1020 & 31.20 & 49.91 & 59.97 \\
16 & 70.20 & 70.18 & 6.41 & 6.18 & 0.0816 & 0.1632 & 66.00 & 33.00 & -50.01 \\
17 & Average crystallite size & & & & & 42.51 & 45.62 & 7.32 \\
\hline
\end{tabular}

FWHM: Full width half maximum, "denotes the percentage change in the crystallite size of Biofield Energy Treated sample with respect to the control sample.

The other XRD parameters such as relative intensities of the PXRD peaks in the Biofield Energy Treated sodium selenate were significantly changed compared to the control sample. It has been reported that XRD relative intensity of each diffraction face on crystalline compound changes according to the crystal morphology [49]. The literature demonstrated that alterations in the XRD pattern due to the polymorphic transitions [50-52]. Hence, changes in the crystallite size and relative intensities of PXRD peaks revealed that the crystal morphology of the Biofield Energy Treated sample was modified compared with the control sample. Thus, it is anticipated that the change in the crystal morphology of the sodium selenate was due to the Biofield Energy Healing Treatment (The Trivedi Effect ${ }^{\mathbb{B}}$ ) and this probably leads to a new polymorphic form of sodium selenate. Crystal habit, size and even polymorphic form of a drug have the effect on drug solubility and bioavailability [53]. Thus, it is inferred that The Trivedi Effect ${ }^{\mathbb{B}}-$ Energy of
Consciousness Healing Treatment might help for improving the bioavailability of sodium selenate.

\subsection{Particle Size Distribution (PSD) Analysis}

The particle size values of the control sodium selenate at $\mathrm{d}_{10}, \mathrm{~d}_{50}$, and $\mathrm{d}_{90}$ were $4.68 \mu \mathrm{m}, 21.01 \mu \mathrm{m}$, and $63.45 \mu \mathrm{m}$, respectively. The particle size values at $\mathrm{d}_{10}, \mathrm{~d}_{50}$, and $\mathrm{d}_{90}$ of the Biofield Energy Treated sodium selenate were $5.00 \mu \mathrm{m}$, $22.70 \mu \mathrm{m}$, and $65.38 \mu \mathrm{m}$, respectively (Table 2 ). Thus, the particle size values at $d_{10}, d_{50}$, and $d_{90}$ of the Biofield Energy Treated sodium selenate were increased by $6.84 \%, 8.04 \%$, and $3.04 \%$, respectively with respect to the control sample. The surface area analysis demonstrated that the surface area of the Biofield Energy Treated sodium selenate $\left(0.50 \mathrm{~m}^{2} / \mathrm{g}\right)$ was significantly decreased by $7.41 \%$ compared with the control sample $\left(0.54 \mathrm{~m}^{2} / \mathrm{g}\right)$ (Table 2$)$.

Table 2. Particle size data $\left(d_{10,} d_{50}\right.$, and $\left.d_{90}\right)$ and surface area of the control and Biofield Energy Treated sodium selenate.

\begin{tabular}{lllll}
\hline Parameter & $\mathbf{d}_{\mathbf{1 0}}(\boldsymbol{\mu m})$ & $\mathbf{d}_{\mathbf{5 0}}(\boldsymbol{\mu m})$ & $\mathbf{d}_{\mathbf{9 0}}(\boldsymbol{\mu m})$ & Surface $\mathbf{a r e a}\left(\mathbf{m}^{\mathbf{2}} / \mathbf{g}\right)$ \\
\hline Control & 4.68 & 21.01 & 63.45 & 0.54 \\
Biofield Treated & 5.00 & 22.70 & 65.38 & 0.50 \\
Percent change* $(\%)$ & 6.84 & 8.04 & 3.04 & -7.41 \\
\hline
\end{tabular}

*denotes the percentage change in the particle size data $\left(\mathrm{d}_{10}, \mathrm{~d}_{50}\right.$, and $\left.\mathrm{d}_{90}\right)$ and surface area of Biofield Energy Treated sample with respect to the control sample.

The particle size and surface area of a compound play a vital role in the solubility, absorption, dissolution and bioavailability of the pharmaceuticals $[43,54]$. The introduction of the external force leads to the transform the fine particles into larger particles. The various reasons to increase the particle size enhanced the flowability, improved product shape and appearance $[55,56]$. It is assumed that Biofield Energy Healing Treatment might improve the flowability, shape, and appearance of sodium selenate.

\subsection{Fourier Transform Infrared (FT-IR) Spectroscopy}

The FT-IR spectra of the control and Biofield Energy Treated samples are represented in Figure 2. The scientific literature reported that the water molecules in the lattice structure of the crystalline inorganic compounds responsible for the characteristic absorption bands in the $3800-3200 \mathrm{~cm}^{-1}$ and $1700-1600 \mathrm{~cm}^{-1}$ regions due to the $\mathrm{O}-\mathrm{H}$ stretching and bending for the water molecules, respectively [57]. The control IR spectrum displayed the $\mathrm{O}-\mathrm{H}$ stretching and bending absorption bands at 3439,1771 , and $1635 \mathrm{~cm}^{-1}$, respectively. In addition, peaks for the $\mathrm{O}-\mathrm{H}$ stretching and bending of the water molecules in the Biofield Energy Treated sample were found at 3440,1771 , and $1631 \mathrm{~cm}^{-1}$. The fingerprint region of the Biofield Energy Treated and control samples was remained unchanged. The $\mathrm{M}=\mathrm{O}$ (metaloxide) stretching absorption band for inorganic materials was found in the 1010-850 $\mathrm{cm}^{-1}$ region [57]. A sharp and strong absorption bands at $887 \mathrm{~cm}^{-1}$ due to the $\mathrm{Se}=\mathrm{O}$ stretching were found in the control sample, while Biofield Energy Treated sample exhibited this peak at $888 \mathrm{~cm}^{-1}$. The analysis indicated that structure of the Biofield Energy Treated sodium selenate was remained same compared with the control sample. 

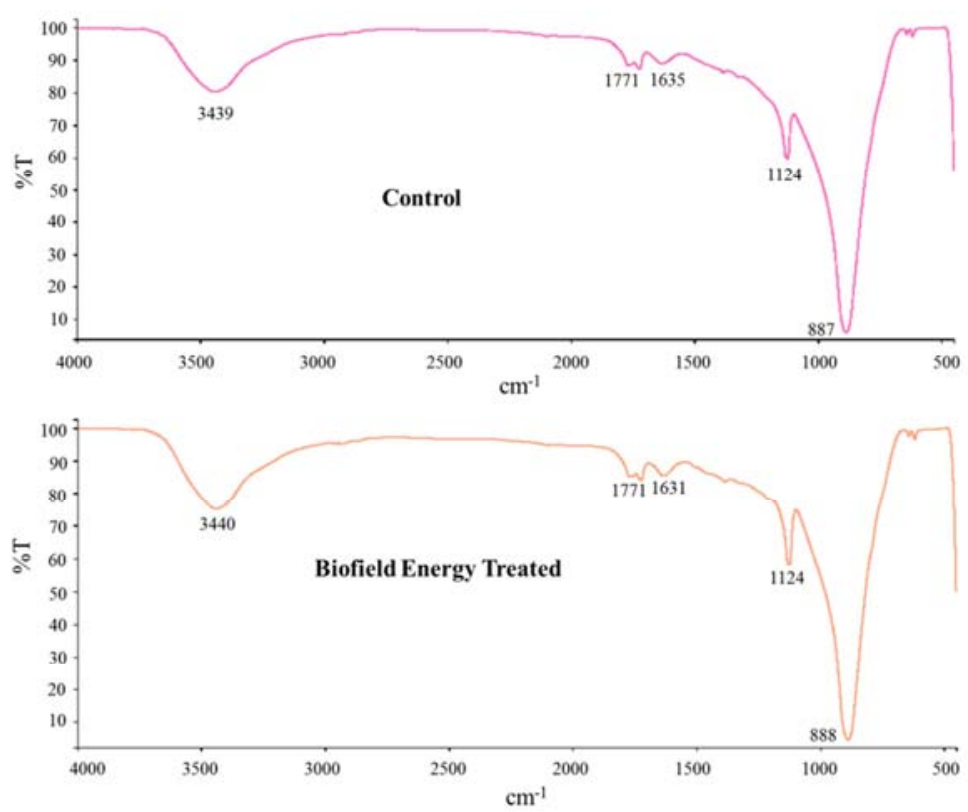

Figure 2. FT-IR spectra of the control and Biofield Energy Treated sodium selenate.

\subsection{Ultraviolet-Visible Spectroscopy (UV-Vis) Analysis}

The wavelength of maximum absorbance $\left(\lambda_{\max }\right)$ of the control and Biofield Energy Treated sodium selenate were at $204.4 \mathrm{~nm}$ and $205.2 \mathrm{~nm}$, respectively and there was a minor move of absorbance maxima from 2.5493 in the control sample to 2.5516 in the Biofield Energy Treated sample. However, the $\lambda_{\max }$ of the Biofield Energy Treated sample was increased by $0.39 \%$ in comparison with the control sample. As there was a slight increase in the $\lambda_{\max }$ of the Biofield Energy Treated sample as compared to the control, it is anticipated that the structural configuration or activation energy of sodium selenate might alter due to The Trivedi Effect $^{\circledR}$ - Consciousness Energy Healing Treatment.

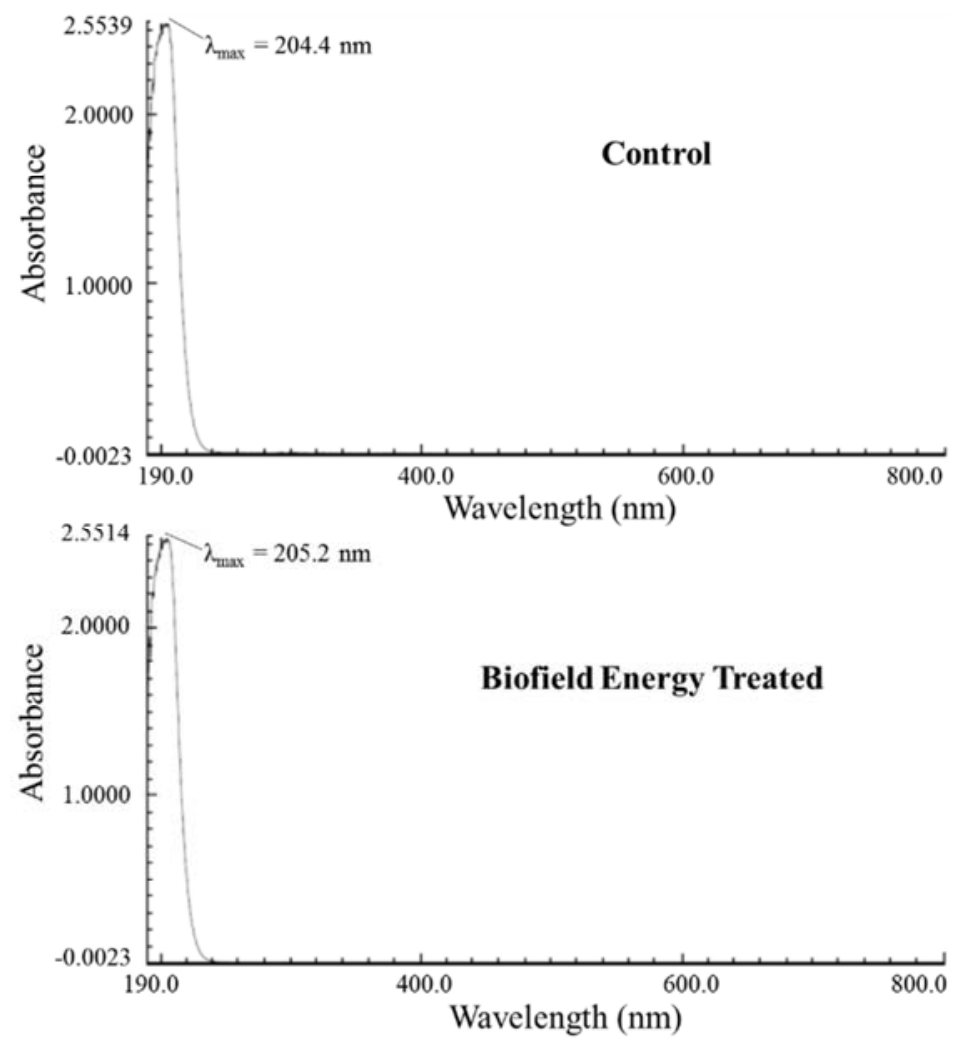

Figure 3. UV-vis spectra of the control and Biofield Energy Treated sodium selenate. 


\subsection{Thermal Gravimetric Analysis (TGA)}

The TGA thermograms of the control and treated samples are shown in Figure 4. Sodium selenate showed one steps of thermal degradation process. The TGA thermogram of the control sample exhibited $4.67 \%$ weight loss from $47.09^{\circ} \mathrm{C}$ to $894.61^{\circ} \mathrm{C}$. Consequently, the TGA thermogram of the Biofield Energy Treated sample showed $4.08 \%$ weight loss from $30.59^{\circ} \mathrm{C}$ to $895.90^{\circ} \mathrm{C}$. The weight loss of the treated sample was significantly reduced by $12.63 \%$ compared with the control sample. This result indicates, it is assumed that Consciousness Energy Healing Treatment (The Trivedi Effect ${ }^{\circledR}$ ) might improve the thermal stability of sodium selenate. The thermal stability of a solid compound plays an important role in the quality, efficacy, and safety in a drug formulation during the manufacturing process, storage, shipment, etc. [58]. It is assumed that Biofield Energy Treated sodium selenate would have better therapeutic efficacy than untreated sample.

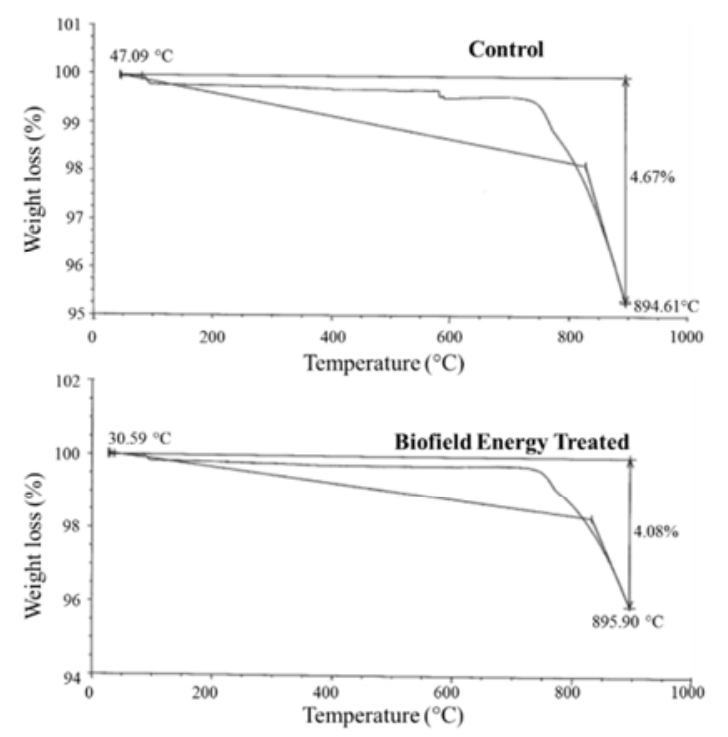

Figure 4. TGA thermograms of the control and Biofield Energy Treated sodium selenate.

\subsection{Differential Scanning Calorimetry (DSC) Analysis}

The DSC thermogram of the control sample showed the presence of a sharp endothermic inflection at $94.28^{\circ} \mathrm{C}$ which was due to evaporation of the bound water and the latent heat of vaporization $\left(\Delta \mathrm{H}_{\text {vaporization }}\right)$ was $7.03 \mathrm{~J} / \mathrm{g}$ (Figure 5 and Table 3). Consequently, the Biofield Energy Treated sodium selenate showed this endothermic peak at $95.14^{\circ} \mathrm{C}$ along with $\Delta \mathrm{H}_{\text {vaporization }}$ of $3.96 \mathrm{~J} / \mathrm{g}$. This suggested that the temperature of the evaporation of the bound water in the Biofield Energy Treated sample was slightly $(0.91 \%)$ increased, whereas the $\Delta \mathrm{H}_{\text {vaporization }}$ was decreased significantly by $43.67 \%$ compared to the control sample.
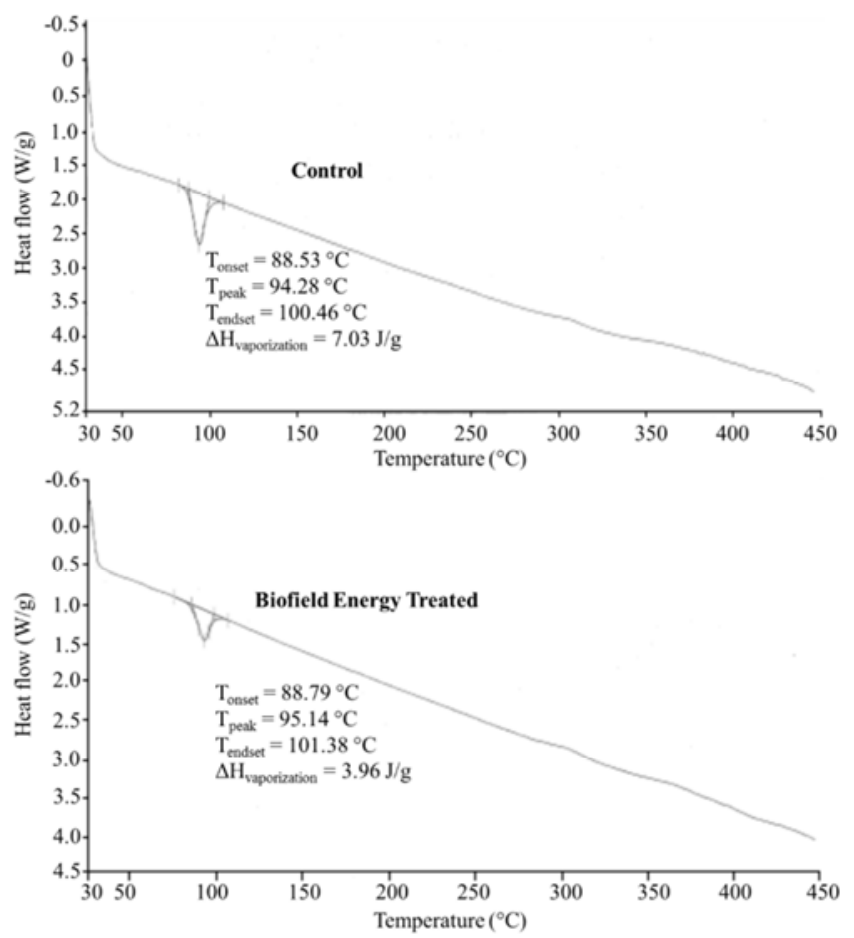

Figure 5. DSC thermograms of the control and Biofield Energy Treated sodium selenate.

Table 3. Comparison of DSC data between the control and Biofield Energy Treated sodium selenate.

\begin{tabular}{lllll}
\hline Sample & $\begin{array}{l}\text { Onset vaporization } \\
\text { temperature }\left(\mathbf{T}_{\text {onset }}\right){ }^{\circ} \mathbf{C}\end{array}$ & $\begin{array}{l}\text { Peak vaporization } \\
\text { temperature }\left(\mathbf{T}_{\text {peak }}\right){ }^{\circ} \mathbf{C}\end{array}$ & $\begin{array}{l}\text { Endset vaporization } \\
\text { temperature }\left(\mathbf{T}_{\text {endset }}\right){ }^{\circ} \mathbf{C}\end{array}$ & $\begin{array}{l}\text { Latent heat of vaporization } \\
\left(\Delta \mathbf{H}_{\text {vaporization }}\right) \mathbf{J} / \mathbf{g}\end{array}$ \\
\hline Control & 88.53 & 94.28 & 100.46 & 7.03 \\
Biofield Energy Treated & 88.79 & 95.14 & 101.38 & 3.96 \\
\% Change* & 0.29 & 0.91 & 0.92 & -43.67 \\
\hline
\end{tabular}

*denotes the percentage change of Biofield Energy Treated sample with respect to the control sample.

\section{Conclusions}

The current analysis revealed that The Trivedi Effect ${ }^{\circledR}$ Energy of Consciousness Healing Treatment displayed the significant impact on the physical, structural, thermal, and behavioral properties of sodium selenate. The PXRD analysis showed the remarkable alteration of the crystallite size of the treated sample from $-50.01 \%$ to $59.97 \%$ compared with the control sample. Overall, the average crystallite size of the treated sodium selenate was significantly increased by $7.32 \%$ compared with the control sample. This result indicated that the crystal morphology of the treated sodium selenate was changed from the control sample and The Trivedi Effect ${ }^{\circledR}$ Biofield Energy Healing might lead to a new polymorphic form of sodium selenate. The particle size of the Biofield Energy Treated sample at $\mathrm{d}_{10}, \mathrm{~d}_{50}$, and $\mathrm{d}_{90}$ values were significantly increased by $6.84 \%, 8.04 \%$, and $3.04 \%$, respectively compared with the control sample. Therefore, 
the surface area of the treated sample was significantly decreased by $7.41 \%$ compared with the control sample. The wavelength of maximum absorbance of the Biofield Energy Treated sample was increased by $0.39 \%$ in comparison with the control sample. TGA analysis revealed that the total weight loss of the Biofield Energy Treated sample was reduced significantly by $12.63 \%$ compared with the control sample. The DSC analysis revealed that the vaporization temperature of the treated sample $\left(95.14^{\circ} \mathrm{C}\right)$ was increased compared to the control sample $\left(94.28^{\circ} \mathrm{C}\right)$. The latent heat of vaporization was decreased significantly in the Biofield Energy Treated sample by $43.67 \%$ compared to the control sample. Briefly, the Biofield Energy Treated sodium selenate might be a new polymorphic form of sodium selenate having increased crystallite and particle size and decreased surface area. Thus, The Trivedi Effect ${ }^{\mathbb{B}}$ treated sodium selenate could be better powder flowability and long-term storage stability compared with the control sample. Hence, The Biofield Energy Treated sodium selenate would be very useful to design better nutraceutical and pharmaceutical formulations that might offer better therapeutic response against various diseases such as diabetes, allergies, septic shock, sleep disorder, insomnia, anxiety, depression, Attention Deficit Hyperactive Disorder (ADHD), brain frog, low libido, impotency, mood swings, fear of the future, lack of motivation, confusion, migraines, headaches, overwhelm, loneliness, worthlessness, forgetfulness, indecisiveness, frustration, irritability, chronic fatigue; inflammatory diseases and immunological disorders like Systemic Lupus Erythematosus, Hashimoto Thyroiditis, Asthma, Chronic peptic ulcers, Hepatitis, Chronic active hepatitis, Tuberculosis, Addison Disease, Crohn's disease, Graves' Disease, Pernicious, Sjogren Syndrome, Irritable Bowel Syndrome (IBS), Aplastic Anemia, Multiple Sclerosis, Chronic periodontitis, Ulcerative colitis, Chronic sinusitis, Rheumatoid arthritis, Myasthenia Gravis, Atherosclerosis, Vasculitis, Dermatitis, Diverticulitis, Alopecia Areata, Psoriasis, Scleroderma, Fibromyalgia, cardiovascular disease, cancer, dementia, cataracts, osteoporosis, Alzheimer's disease, hypertension, glaucoma, hearing loss, Parkinson's Disease, Prion Disease, Motor Neuron Disease, Huntington's Disease, Spinal muscular atrophy, Spinocerebellar Ataxia, Amyotrophic lateral sclerosis, Lewy Body Disease, Friedreich's Ataxia, chronic infections and much more.

\section{Abbreviations}

DSC: Differential scanning calorimetry, FT-IR: Fourier transform infrared spectroscopy, FWHM: Full width half maximum, G: Crystallite size, HOMO: Highest energy occupied molecular orbital, LUMO: Lowest energy unoccupied molecular orbital, TGA: Thermal gravimetric analysis, $\mathrm{T}_{\text {onset }}$ : Onset melting temperature, $\mathrm{T}_{\text {peak }}$ : Peak melting temperature, $\mathrm{T}_{\text {endset }}$ : Endset melting temperature, $\Delta \mathrm{H}_{\text {vaporization }}$ : Latent heat of vaporization, UV-vis: Ultravioletvisible spectroscopy, PSD: Particle size distribution, PXRD: Powder X-ray diffraction.

\section{Acknowledgements}

The authors are grateful to GVK Biosciences Pvt. Ltd., Trivedi Science, Trivedi Global, Inc. and Trivedi Master Wellness for their assistance and support during this work.

\section{References}

[1] Kamburov S, Schmidt H, Voigt W, Balarew C (2014) Similarities and peculiarities between the crystal structures of the hydrates of sodium sulfate and selenate. Acta Crystallogr B Struct Sci Cryst Eng Mater 70: 714-722.

[2] Cardoso BR, Ong TP, Jacob-Filho W, Jaluul O, Freitas MI, Cozzolino SM (2010). Nutritional status of selenium in Alzheimer's disease patients. Br J Nutr 103: 803-806.

[3] Chen J, Berry MJ (2003) Selenium and selenoproteins in the brain and brain diseases. J Neurochem 86: 1-12.

[4] Ani M, Moshtaghie AA, Aghadavod M (2007) Protective effects of selenium and zinc on the brain acetylcholinesterase activity in lead intoxified rat. Research in Pharmaceutical Sciences 2: 80-84.

[5] Abubakar MG, Taylor A, Ferns GA (2004) The effects of aluminium and selenium supplementation on brain and liver antioxidant status in the rat. Afr J Biotechnol 3: 88-93.

[6] Fleet JC (1997) Dietary selenium repletion may reduce cancer incidence in people at high risk who live in areas with low soil selenium. Nutr Rev 55: 277-279.

[7] Moshtaghie AA, Ani M, Aghadavood E, Fazilati M (2007) Protective effects of selenium and zinc on changes in catecholamine levels of brain regions in lead intoxified rat. Pak J Bio Sci 10: 2964-2967.

[8] https://en.wikipedia.org/wiki/Sodium_selenate.

[9] Krieger RI (2001) Handbook of pesticide toxicology. Volume 1; Academic Press. San Diego, CA, $2^{\text {nd }}$ edition, pp 1908.

[10] Hanson B, Lindblom SD, Loeffler ML, Pilon-Smits EAH (2004) Selenium protects plants from phloem-feeding aphids due to both deterrence and toxicity. New Phytologist 162: 655-662.

[11] Podoll KL, Bernard JB, Ullrey DE, DeBar SR, Ku PK, Magee WT (1992) Dietary selenate versus selenite for cattle, sheep, and horses. J Anim Sci 70: 1965-1970.

[12] Ganther HE, Baumann CA (1962) Selenium metabolism. II. Modifying effects of sulfate. J Nutr 77: 408-414.

[13] Dietary Supplement Fact Sheet: Selenium. http://ods.od.nih.gov/factsheets/selenium.

[14] http://www.tucson.ars.ag.gov/unit/publications/PDFfiles/1404. pdf.

[15] Raymond LJ, Deth RC, Ralston NVC (2014) Potential role of selenoenzymes and antioxidant metabolism in relation to autism etiology and pathology. Autism Research and Treatment 2014: 164938.

[16] Haug A, Graham RD, Christophersen OA, Lyons GH (2007) How to use the world's scarce selenium resources efficiently to increase the selenium concentration in food. Microb Ecol Health Dis 19: 209-228. 
[17] Combs GF Jr (2001) Selenium in global food systems. Br J Nutr 85: 517-547.

[18] Brower V (1998) Nutraceuticals: Poised for a healthy slice of the healthcare market? Nat Biotechnol 16: 728-731.

[19] Rubik B (2002) The biofield hypothesis: Its biophysical basis and role in medicine. J Altern Complement Med 8: 703-717.

[20] Nemeth L (2008) Energy and biofield therapies in practice. Beginnings 28: 4-5.

[21] Rivera-Ruiz M, Cajavilca C, Varon J (2008) Einthoven's string galvanometer: The first electrocardiograph. Tex Heart Inst J 35: $174-178$.

[22] Koithan M (2009) Introducing complementary and alternative therapies. J Nurse Pract 5: 18-20.

[23] Trivedi MK, Tallapragada RM, Branton A, Trivedi D, Nayak G, Latiyal O, Jana S (2015) Characterization of physical and structural properties of aluminium carbide powder: impact of biofield treatment. J Aeronaut Aerospace Eng 4: 142.

[24] Trivedi MK, Nayak G, Patil S, Tallapragada RM, Latiyal O, Jana S (2015) Impact of biofield treatment on atomic and structural characteristics of barium titanate powder. Ind Eng Manage 4: 166.

[25] Trivedi MK, Patil S, Nayak G, Jana S, Latiyal O (2015) Influence of biofield treatment on physical, structural and spectral properties of boron nitride. J Material Sci Eng 4: 181.

[26] Trivedi MK, Branton A, Trivedi D, Nayak G, Bairwa K, Jana S (2015) Spectroscopic characterization of disodium hydrogen orthophosphate and sodium nitrate after biofield treatment. J Chromatogr Sep Tech 6: 282.

[27] Trivedi MK, Branton A, Trivedi D, Nayak G, Bairwa K, Jana S (2015) Impact of biofield treatment on spectroscopic and physicochemical properties of $p$-nitroaniline. Insights in Analytical Electrochemistry 1: 1-8.

[28] Trivedi MK, Branton A, Trivedi D, Nayak G, Bairwa K, Jana S (2015) Fourier transform infrared and ultraviolet-visible spectroscopic characterization of ammonium acetate and ammonium chloride: An impact of biofield treatment. Mod Chem Appl 3: 163.

[29] Trivedi MK, Tallapragada RM, Branton A, Trivedi D, Nayak G, Latiyal O, Mishra RK, Jana S (2015) Physicochemical characterization of biofield treated calcium carbonate powder. American Journal of Health Research 3: 368-375.

[30] Trivedi MK, Tallapragada RM, Branton A, Trivedi D, Nayak G, Latiyal O, Jana S (2015) Physical, atomic and thermal properties of biofield treated lithium powder. J Adv Chem Eng 5: 136.

[31] Trivedi MK, Patil S, Shettigar H, Bairwa K, Jana S (2015) Phenotypic and biotypic characterization of Klebsiella oxytoca: An impact of biofield treatment. J Microb Biochem Technol 7: 203-206.

[32] Trivedi MK, Branton A, Trivedi D, Nayak G, Mondal SC, Jana S (2015) In vitro evaluation of biofield treatment on viral load against human immunodeficiency-1 and cytomegalo viruses. American Journal of Health Research. 3: 338-343.

[33] Trivedi MK, Patil S, Shettigar H, Mondal SC, Jana S (2015)
In vitro evaluation of biofield treatment on Enterobacter cloacae: Impact on antimicrobial susceptibility and biotype. J Bacteriol Parasitol 6: 241.

[34] Trivedi MK, Patil S, Shettigar H, Mondal SC, Jana S (2015) Evaluation of biofield modality on viral load of Hepatitis B and C viruses. J Antivir Antiretrovir 7: 083-088.

[35] Trivedi MK, Branton A, Trivedi D, Shettigar H, Nayak G, Gangwar M, Jana S (2015) Assessment of antibiogram of multidrug-resistant isolates of Enterobacter aerogenes after biofield energy treatment. J Pharma Care Health Sys 2: 145 .

[36] Trivedi MK, Branton A, Trivedi D, Nayak G, Gangwar M, Jana S (2015) Effect of biofield energy treatment on chlorophyll content, pathological study, and molecular analysis of cashew plant (Anacardium occidentale L.). Journal of Plant Sciences 3: 372-382.

[37] Trivedi MK, Branton A, Trivedi D, Nayak G, Mondal SC, Jana S (2015) Morphological characterization, quality, yield and DNA fingerprinting of biofield treated alphonso mango (Mangifera indica L.). Journal of Food and Nutrition Sciences 3: 245-250.

[38] Trivedi MK, Branton A, Trivedi D, Nayak G, Mishra RK, Jana S (2015) Characterization of physical, thermal and spectral properties of biofield treated date palm callus initiation medium. International Journal of Nutrition and Food Sciences 4: 660-668.

[39] Trivedi MK, Branton A, Trivedi D, Nayak G, Bairwa K, Jana S (2015) Physical, thermal, and spectroscopic characterization of biofield energy treated murashige and skoog plant cell culture media. Cell Biology 3: 50-57.

[40] Trivedi MK, Branton A, Trivedi D, Nayak G, Mishra RK, Jana S (2015) Comparative physicochemical evaluation of biofield treated phosphate buffer saline and hanks balanced salt medium. American Journal of BioScience 3: 267-277.

[41] Trivedi MK, Patil S, Shettigar H, Bairwa K, Jana S (2015) Evaluation of phenotyping and genotyping characterization of Serratia marcescens after biofield treatment. J Mol Genet Med 9: 179.

[42] Trivedi MK, Branton A, Trivedi D, Nayak G, Charan S, Jana S (2015) Phenotyping and 16S rDNA analysis after biofield treatment on Citrobacter braakii: A urinary pathogen. J Clin Med Genom 3: 129.

[43] Chereson R (2009) Bioavailability, bioequivalence, and drug selection. In: Makoid CM, Vuchetich PJ, Banakar UV (Eds) Basic pharmacokinetics ( $1^{\text {st }}$ Edn) Pharmaceutical Press, London.

[44] Trivedi MK, Mohan TRR (2016) Biofield energy signals, energy transmission and neutrinos. American Journal of Modern Physics 5: 172-176.

[45] Trivedi MK, Branton A, Trivedi D, Nayak G, Lee AC, Hancharuk A, Sand CM, Schnitzer DJ, Thanasi R, Meagher EM, Pyka FA, Gerber GR, Stromsnas JC, ShapiroJM, Streicher LN, Hachfeld LM, Hornung MC, Rowe PM, Henderson SJ, Benson SM, Holmlund ST, Salters SP, Panda P, Jana S (2017) Investigation of physicochemical, spectral, and thermal properties of sodium selenate treated with the Energy of Consciousness (The Trivedi Effect ${ }^{\mathbb{B}}$ ). American Journal of Life Sciences 5: 27-37. 
[46] Trivedi MK, Branton A, Trivedi D, Nayak G, Nykvist CD, Lavelle C, Przybylski DP, Vincent DH, Felger D, Konersman DJ, Feeney EA, Prague JA, Starodub JL, Rasdan K, Strassman KM, Soboleff L, Mayne MA, Keesee MM, Pillai PN, Ansley PC, Schmitz RD, Sodomora SM, Sethi KK, Panda P, Jana S (2017) Evaluation of the physicochemical, spectral, and thermal properties of sodium selenate treated with the Energy of Consciousness (The Trivedi Effect ${ }^{\mathbb{B}}$ ). Advances in Bioscience and Bioengineering 5: 12-21.

[47] Alexander L, Klug HP (1950) Determination of crystallite size with the X-ray spectrometer. J App Phys 21: 137.

[48] Langford JI, Wilson AJC (1978) Scherrer after sixty years: A survey and some new results in the determination of crystallite size. J Appl Cryst 11: 102-113.

[49] Inoue M, Hirasawa I (2013) The relationship between crystal morphology and XRD peak intensity on $\mathrm{CaSO}_{4} \cdot 2 \mathrm{H}_{2} \mathrm{O}$. J Crystal Growth 380: 169-175.

[50] Raza K, Kumar P, Ratan S, Malik R, Arora S (2014) Polymorphism: The phenomenon affecting the performance of drugs. SOJ Pharm Pharm Sci 1: 10.

[51] Thiruvengadam E, Vellaisamy G (2014) Polymorphism in pharmaceutical ingredients a review. World Journal of Pharmacy and Pharmaceutical Sciences 3: 621-633.
[52] Brittain HG (2009) Polymorphism in pharmaceutical solids in Drugs and Pharmaceutical Sciences, volume 192, $2^{\text {nd }}$ Edn, Informa Healthcare USA, Inc., New York.

[53] Blagden N, de Matas M, Gavan PT, York P (2007) Crystal engineering of active pharmaceutical ingredients to improve solubility and dissolution rates. Adv Drug Deliv Rev 59: 617630 .

[54] Khadka P, Ro J, Kim H, Kim I, Kim JT, Kim H, Cho JM, Yun G, Lee J (2014) Pharmaceutical particle technologies: An approach to improve drug solubility, dissolution and bioavailability. Asian J Pharm Sci 9: 304-316.

[55] Kale VV, Gadekar S, Ittadwar AM (2011) Particle size enlargement: Making and understanding of the behavior of powder (particle) system. Syst Rev Pharm 2: 79.

[56] Podczeck F, Mia Y (1996) The influence of particle size and shape on the angle of internal friction and the flow factor of unlubricated and lubricated powders. Int J Pharm 144: 187194.

[57] Stuart BH (2004) Infrared spectroscopy: Fundamentals and applications in Analytical Techniques in the Sciences. John Wiley \& Sons Ltd., Chichester, UK.

[58] Bajaj S, Singla D, Sakhuja N (2012) Stability testing of pharmaceutical products. J App Pharm Sci 2: 129-138. 